\title{
This variant alters protein function, but is it pathogenic?
} OPEN

Massimo Pandolfo, MD

Correspondence to Dr. Pandolfo: massimo.pandolfo@ulb.ac.be

\section{Neurol Genet}

2017;3:e173; doi: 10.1212/ NXG.0000000000000173

\section{See article}

Identifying the causative mutation for a mendelian disease among several, or many, genetic variants represents a challenge, even more so with the increasing use of next-generation sequencing for genetic diagnosis. In 2015, the American College of Medical Genetics and Genomics (ACMG) and the Association for Molecular Pathology (AMP) proposed guidelines to classify variants in genes associated with mendelian diseases according to their potential pathogenicity. ACMG-AMP rules include genetic criteria such as population, segregation, de novo, allelic, and database data, along with functional criteria, including computational and predictive data and functional studies. When the same amino acid change is found as in an established pathogenic variant, this is considered strongly supportive of pathogenicity. Functional studies showing a deleterious effect are also strongly supportive of pathogenicity.

In this issue of Neurology ${ }^{\circledR}$ Genetics, McNeill et al. ${ }^{2}$ report the finding by whole-exome sequencing (WES) of compound heterozygous variants in the EARS2 gene in a patient with leukoencephalopathy. EARS2, encoding mitochondrial glutamyl-tRNA synthetase, is mutated in the autosomal recessive leukoencephalopathy with thalamus and brainstem involvement and high lactate (LTBL). ${ }^{3}$ One of the variants detected in this patient, c.328G $>$ A (p.G110S), had previously been found in multiple patients with LTBL. In silico analysis supported pathogenicity of the other variant (c.1045G $>$ A, p.E349K) as well. Furthermore, McNeill et al. performed functional analyses in patient skin fibroblasts, finding a significant decrease in EARS2 protein levels to $30 \%$ of normal controls, along with an $\sim 11 \%$ decrease in the oxygen consumption rate and $\sim 43 \%$ decrease in the maximal respiratory rate compared with control. Mitochondrial dysfunction was corrected by the expression of wild-type EARS2 protein. Taken together, these results seemed to provide strong evidence supporting pathogenicity of the identified EARS2 variants.
However, one important piece did not fit in the puzzle. In the original description of LTBL, brain MRI findings were characterized in all patients by extensive symmetrical cerebral white matter abnormalities sparing the periventricular rim and by symmetrical signal abnormalities of the thalami, midbrain, pons, medulla oblongata, and cerebellar white matter. As indicated in the name of the disease, brain lactate, measured by proton magnetic resonance spectroscopy (MRS), was increased. LTBL is not limited to the nervous system, as it may cause liver abnormalities and increased lactate in all body fluids. Of interest, clinical, MRI, and MRS follow-up of patients with LTBL allowed us to identify a "severe" subgroup showing early postnatal onset with failure to thrive and hypotonia then spastic tetraparesis, dystonia, visual impairment, and seizures, followed by clinical stagnation, brain atrophy, and persisting high lactate levels; and a "mild" subgroup, showing later clinical onset, most often in the second half of the first year of life, with spasticity, loss of milestones, occasional seizures, and extreme irritability, followed by partial clinical recovery, MRI improvement, and declining lactate levels. ${ }^{3}$

The patient studied by McNeill et al. neither showed the unique neuroimaging features of LTBL nor presented the peculiar biphasic clinical course of this disease. Their patient was a 6-year-old boy with a progressive encephalopathy consisting of intellectual disability, refractory seizures, dystonia, chorea, and spasticity, who died at the age of 16 after a progressive disease course. MRI showed a diffuse leukoencephalopathy with multiple calcifications affecting gray matter nuclei, juxtacortical U-fibers, subcortical and periventricular white matter, brainstem, and the dentate nucleus of the cerebellum, while MRS showed no increase in lactate. Autopsy showed a severe vasculopathy causing ischemic lesions, calcifications, white matter degeneration, and cyst formation. This clinical, imaging, and pathologic features are strongly suggestive of a condition called leukoencephalopathy,

From the Department of Neurology, Hôpital Erasme and Laboratory of Experimental Neurology, Université Libre de Bruxelles, Belgium.

Funding information and disclosures are provided at the end of the article. Go to Neurology.org/ng for full disclosure forms. The Article Processing Charge for this editorial was waived at the discretion of the Editor.

This is an open access article distributed under the terms of the Creative Commons Attribution-NonCommercial-NoDerivatives License 4.0 (CC BY-NC-ND), which permits downloading and sharing the work provided it is properly cited. The work cannot be changed in any way or used commercially without permission from the journal. 
brain calcifications, and cysts (LCC), ${ }^{4}$ which is strictly limited to the nervous system and not associated with increased lactate.

So, if the phenotype of this patient was clearly different from LTBL and rather fitting a different condition, LCC, what to do of the putative EARS2 mutations? Does this case extend the phenotypic spectrum linked to EARS2 mutation? Or conversely, are the EARS2 variants unrelated to the LCC phenotype of this patient? And, if the latter is the case, have the EARS2 variants modified the patient's phenotype?

$\mathrm{McNeill}$ et al. found a partial answer to these questions when they realized that their patient had also been independently investigated in a genetic study on LCC and found to carry compound heterozygous mutations in SNORD118, encoding a small nucleolar RNA involved in ribosome biogenesis. ${ }^{5}$ SNORD118 was also mutated in additional LCC families, identifying it as a causative gene for this condition. Based on this finding, they conclude "that the presence of the SNORD118 mutations as the pathogenic driver of LCC relegates the functionally pathogenic EARS2 variants in this case to an unknown status."

What lessons can we draw from this report? First, rigorous characterization of the phenotype is essential for the interpretation of genetic test results. This is not as trivial as it may seem because examples abound of mutations in different genes causing highly similar phenotypes and of mutations in the same gene causing very different phenotypes. The very concept of "reverse phenotyping" is based on the latter point. However, in many cases, some core clinical and paraclinical features may enable to predict how likely is the involvement of a specific gene. In the case described by McNeill et al., normal levels of lactate in the brain and in body fluids argued against an EARS2-linked phenotype, even more than structural MRI features and atypical clinical course. The second, probably more unexpected lesson, is that even demonstrating an abnormal function of the encoded protein may not be enough to prove pathogenicity of a genetic variant. In a way, this is just a reiteration of the previous point: if the phenotype does not reflect the observed in vitro abnormalities, a different cause is possible and even likely.

Finally, the question whether seemingly pathogenic EARS2 mutations in this patient may have somehow modified his phenotype remains open. Even if the expected increase in lactate did not occur, subclinical mitochondrial dysfunction may have worsened the consequence of the microangiopathy of LCC, but the reported data do not allow us to test this hypothesis. More generally, a combination of clinical observation of multiple cases with experimental data from animal models may allow to address the issue of how potentially pathogenic mutations in different genes interact and eventually determine the phenotype. Recently, a study from Baylor College of Medicine on more than 2,000 patients receiving a molecular diagnosis after WES showed that $4.9 \%$ of them carried seemingly pathogenic mutations in 2 loci. $^{6}$ These patients showed either distinct disease phenotypes, with individual phenotypic features attributable to only 1 of the 2 diagnoses, or overlapping phenotypes, with phenotypic features attributable to either one of the diagnoses. Overlapping disease phenotypes were observed particularly when the coexisting mutations altered proteins in the same functional pathway. The peculiarity of the patient of McNeill et al., deserving additional investigation, is the apparently "pure" LCC phenotype lacking clinical features attributable to the EARS2 mutations, when an overlapping phenotype might have been expected.

\section{STUDY FUNDING}

No targeted funding reported.

\section{DISCLOSURE}

Massimo Pandolfo has served on the scientific advisory boards of Apopharma and Voyager Therapeutics; has served on the editorial boards of Acta Neurologica Belgica, the Orphanet Journal of Rare Diseases, and Neurology: Genetics; holds a patent for Direct molecular diagnosis of Friedreich's ataxia; has been a consultant for Biomarin; has received research support from Biomarin, Fonds National de la Recherche Scientifique (Belgium), Offrez-moi-la-lune, Friedreich's Ataxia Research Alliance, and Association Belge contre les Maladies Neuro-Musculaires; and has received royalty payments from Athena Diagnostics. Go to Neurology.org/ng for full disclosure forms.

\section{REFERENCES}

1. Richards S, Aziz N, Bale S, et al. Standards and guidelines for the interpretation of sequence variants: a joint consensus recommendation of the American College of Medical Genetics and Genomics and the Association for Molecular Pathology. Genet Med 2015;17:405-424.

2. McNeill N, Nasca A, Reyes A, et al. Functionally pathogenic EARS2 variants in vitro may not manifest a phenotype in vivo. Neurol Genet 2017;3:e162. doi: 10.1212/NXG. 0000000000000162.

3. Steenweg ME, Vanderver A, Ceulemans B, et al. Novel infantile-onset leukoencephalopathy with high lactate level and slow improvement. Arch Neurol 2012;69:718-722.

4. Stephani C, Pfeifenbring S, Mohr A, Stadelmann C. Lateonset leukoencephalopathy with cerebral calcifications and cysts: case report and review of the literature. BMC Neurol 2016;16:1-12.

5. Jenkinson EM, Rodero MP, Kasher PR, et al. Mutations in SNORD118 cause the cerebral microangiopathy leukoencephalopathy with calcifications and cysts. Nat Genet 2016; 48:1185-1192.

6. Posey JE, Harel T, Liu P, et al. Resolution of disease phenotypes resulting from Multilocus Genomic Variation. N Engl J Med 2017;376:21-31. 




This variant alters protein function, but is it pathogenic?

Massimo Pandolfo

Neurol Genet 2017;3;

DOI 10.1212/NXG.0000000000000173

This information is current as of July 14, 2017

\section{Updated Information \&}

Services

Supplementary Material

References

Citations

Permissions \& Licensing

Reprints including high resolution figures, can be found at: http://ng.neurology.org/content/3/4/e173.full.html

Supplementary material can be found at: http://ng.neurology.org/content/suppl/2017/11/06/3.4.e173.DC1

This article cites 6 articles, 1 of which you can access for free at: http://ng.neurology.org/content/3/4/e173.full.html\#\#ref-list-1

This article has been cited by 2 HighWire-hosted articles: http://ng.neurology.org/content/3/4/e173.full.html\#\#otherarticles

Information about reproducing this article in parts (figures,tables) or in its entirety can be found online at:

http://ng.neurology.org/misc/about.xhtml\#permissions

Information about ordering reprints can be found online: http://ng.neurology.org/misc/addir.xhtml\#reprintsus

Neurol Genet is an official journal of the American Academy of Neurology. Published since April 2015, it is an open-access, online-only, continuous publication journal. Copyright Copyright @ 2017 The Author(s). Published by Wolters Kluwer Health, Inc. on behalf of the American Academy of Neurology. All rights reserved. Online ISSN: 2376-7839.

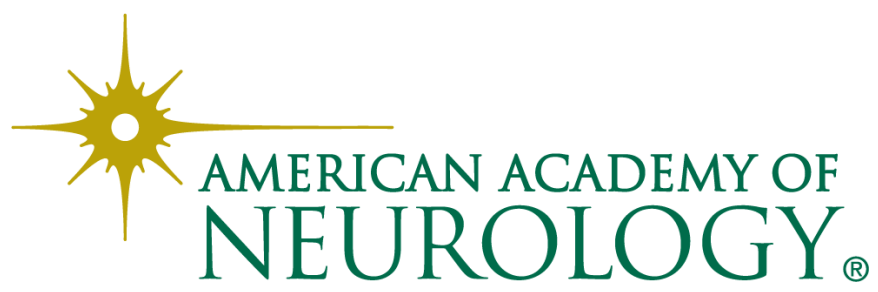

